\section{Pengaruh ekstrak daun rambutan (Nephelium lappaceum L.) terhadap kematian larva nyamuk aedes aegypti Effect of rambutan leaf extract (Nephelium lappaceum L.) on the death of aedes aegypti mosquito larvae}

SAGO: Gizi dan Kesehatan 2019, Vol. 1(1) 73-78 (c) The Author(s) 2019

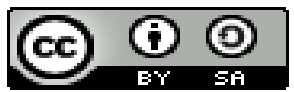

DOI: http://dx.doi.org/10.30867/gikes.v1i1.291 https://ejournal2.poltekkesaceh.ac.id/index.php Lgikes Poltekkes Kemenkes Aceh

\title{
Fajriansyah $^{1}$
}

\begin{abstract}
Background: The effort to control mosquitoes can be done by terminating the life cycle of mosquitoes, eradication of the larval sadium, namely larvicides. Rambutan leaves (Nephelium lappaceum L.) contain tannin compounds, saponins. Saponins are destroying red blood cells through the reaction of hemolysin, are toxic to cold-blooded animals, including cold-blooded insects, one of the insects that often interfere with human life is mosquitoes.

Objectives: The purpose of this study was to determine the extract of rambutan leaves on the death of Aedes aegypti larvae

Methods: This research is an experimental research. The object of research was Aedes aegypti mosquito larvae. The study was conducted at the writer home of Lamjamee Village, Banda Aceh. Research time is August 23-25, 2017. Type of research is an experimental study that is the effect of rambutan leaf extract on the death of Aedes aegypti larvae. The object of research is the population of Aedes aegypti larvae. The research subjects taken were Aedes aegypti mosquito larvae that lived because of the administration of rambutan leaf extract with a concentration of $5 \%, 10 \%$, $15 \%$. Statistical data analysis used Anova LSD test.

Results: The results showed that the death of Aedes aegypti larvae by using rambutan leaf extract (Nephelium lappaceum L.) dose of $5 \%$ with an average of 19.7. Dose $10 \%$ had an average of 34.3 , and a dose of $15 \%$ of the average mortality was 43.7. There is a significant difference between each dose of the mortality rate of Aedes aegypti larvae, with a value of $F=28.1$ ( $F$-count $>$ F-table $=4.07$ ).

Conclusion: Various concentrations of the three treatments of rambutan leaf extract namely $5 \%, 10 \%$ and $15 \%$ are very effective against the death of Aedes aegypti larvae. Suggestions, can be used and practiced in everyday life, so as to reduce the use of chemical insecticides.
\end{abstract}

\section{Keywords}

Rambutan leaves, Aedes aegypti, mosquito larvae

\begin{abstract}
Abstrak
Latar Belakang: Upaya pengendalian nyamuk dapat dilakukan dengan pemutusan siklus hidup nyamuk, pemberantasan pada sadium larva yaitu dengan larvasida. Daun rambutan (Nephelium lappaceum L.) mengandung senyawa tannin, saponin. Saponin bersifat menghancurkan butir darah merah lewat reaksi hemolisin, bersifat racun bagi hewan berdarah dingin, serangga termasuk hewan berdarah dingin salah satu serangga yang sering mengganggu kehidupan manusia adalah nyamuk.

Tujuan: Tujuan penelitian untuk mengetahui ekstrak daun rambutan terhadap kematian larva nyamuk Aedes aegypti.

Metode: Penelitian ini merupakan penelitian eksperimen. Objek penelitian adalah larva nyamuk Aedes aegypti. Penelitian dilaksanakan dirumah penulis Desa Lamjamee Banda Aceh. Waktu penelitian tanggal 23-25 Agustus 2017. Jenis penelitian merupakan penelitian eksperimen yaitu pengaruh ekstrak daun rambutan terhadap kematian larva nyamuk Aedes aegypti. Objek penelitian adalah populasi larva nyamuk aedes aegypti. Subjek penelitian yang diambil
\end{abstract}

${ }^{1}$ Jurusan Kesehatan Lingkungan Politeknik Kesehatan Kemenkes RI Aceh. E-mail: fajri.ansyah@yahoo.co.id 
adalah larva nyamuk Aedes aegypti yang hidup karena pemberian eksfrak daun rambutan dengan konsentrasi 5\%, 10\%, 15\%. Analisis data secara statistik menggunakan Anova LSD.

Hasil: Hasil penelitian menunjukkan bahwa pada kematian larva Aedes aegypti dengan menggunakan ekstrak daun rambutan dosis $5 \%$ dengan rata-rata 19.7 . Dosis $10 \%$ mempunyai rata-rata 34.3 , dan dosis $15 \%$ rata-rata kematian adalah 43.7. Terdapat perbedaan signifikan antara setiap dosis terhadap angka kematian larva nyamuk aedes aegypti, dengan nilai $\mathrm{F}=28.1$ ( F-hitung $>$ F-tabel $=4.07$ ).

Kesimpulan: Berbagai konsentrasi pada ketiga perlakuan ekstrak daun rambutan yaitu 5\%, 10\% dan 15\% sangat efektif terhadap kematian larva nyamuk aedes aegypti. Saran, dapat dimanfaatkan dan dipraktikkan dalam kehidupan seharihari, agar dapat mengurangi penggunaan insektisida kimia.

\section{Kata Kunci}

Daun rambutan, Kematian larva, Aedes aegypti

\section{Pendahuluan}

K esehatan merupakan hak asasi manusia dan salah satu unsur kesejahteraan yang harus diwujudkan sesuai dengan cita-cita bangsa Indonesia sebagaimana dimaksud dalam Pancasila dan Undang-Undang Dasar Negara Republik Indonesia Tahun 1945. Setiap kegiatan dalam upaya untuk memelihara dan meningkatkan derajat kesehatan masyarakat yang setinggi-tingginya dilaksanakan berdasarkan prinsip nondiskriminatif partisipatif, dan berkelanjutan dalam rangka pembentukan sumber daya manusia Indonesia, serta peningkatan ketahanan dan daya saing bangsa bagi pembangunan nasional. Pasal 162 Upaya Kesehatan Lingkungan ditujukan untuk mewujudkan kualitas lingkungan yang sehat, baik fisik, kimia, biologi, maupun sosial yang memungkinkan setiap orang mencapai derajat kesehatan yang setinggi-tingginya (Kemenkes RI, 2013).

Penyakit Demam Berdarah Dengue (DBD) adalah penyakit menular yang disebabkan oleh virus dengue dan ditularkan melalui gigitan nyamuk Aedes aegypti. Jumlah penderita yang DBD yang ditemukan pada tahun 2010 mencapai 156,086 kasus, tahun 2011 sekitar 65,725 kasus, tahun 2012 sekitar 90,245 kasus, tahun 2012 sampai dengan semester I berjumlah 54,694 kasus, tahun 2013 sampai dengan semester I berjumlah 50,348 kasus (Siregar, 2014).

Banyaknya dampak negatif dari penggunaan insektisida kimia memunculkan penelitian baru dalam pengendatian vektor yang lebih aman, sederhana, dan berwawasan lingkungan (Moehammadi, 2005). Pengendalian menggunakan insektisida nabati (bioinsektisida) dari ekstrak tumbuhan adalah salah satunya famili tumbuhan yang dianggap merupakan sumber potensial insektisida nabati adalah Meliacea, Annonaceae,
Astraceae, Piperaceae dan Rutaceae (Listiyati et al., 2012).

Rambutan merupakan tanaman buah hortikultural berupa pohon dengan famili Sapindacaeae. Tanaman buah rambutan sengaja dibudidayakan untuk dimanfaatkan buahnya yang mempunyai gizi, zat tepung, sejenis gula yang mudah terlarut dalam air, zat protein dan asam amino, zat lemak, zat enzim-enzim yang esensial dan nonesensial, vitamin dan zat mineral makro, mikro yang menyehatkan keluarga, tetapi ada pula sementara masyarakat yang memanfaatkan sebagai pohon pelindung dipekarangan ataupun sebagai tanaman hias (Desinta, 2014).

Berdasarkan hasil penelitian Widiyanti \& Muyadihardja (2004) diketahui cara yang tepat dalam pemberantasan penyakit DBD adaiah dengan pengendalian vektor nyamuk sebagai penular. Salah satu upaya pengendalian nyamuk dapat dilakukan dengan pemutusan siklus hidup nyamuk, misalnya pemberantasan pada stadium larva yaitu dengan larvasida. Menurut Amir \& Widiastuti (2018), masyarakat sampai saat ini lebih memilih penggunaan pestisida kimia. Padahal untuk penggunaan pestisida yang berulang-ulang akan menimbulkan masalah baru yaitu membunuh serangga yang bukan target dan timbulnya resistensi.

Hal ini mendorong untuk dikembangkannya alternatif lain dengan menggunakan bahan alami, misalnya bahan dari tumbuhan sebagai pestisida nabati yang relatif lebih aman (Trisawa, 2014), daun rambutan (Naphelium lappceummL.) mengandung senyawa tanin dan saponin (Amir \& Widiastuti, 2018). Saponin bersifat menghancurkan butir darah merah lewat reaksi hemolisis, bersifat racun bagi hewan berdarah dingin dan banyak diantaranya digunakan sebagai racun ikan (Lestari et al., 2014). Serangga termasuk hewan berdarah dingin, salah 
satu serangga yang sering mengganggu kehidupan manusia adalah nyamuk (Amir \& Widiastuti, 2018).

Berdasarkan latar belakang permasalahan diatas terhadap pentingnya pencegahan penyebaran larva nyamuk Aedes aegypti melalui penggunaan bahan alami merupakan pilihan alternatif kepada masyarakat, maka penelitian ini bertujuan untuk mengukur dampak dari ekstrak daun rambutan terhadap kematian larva nyamuk Aedes aegypti.

\section{Metode}

Jenis penelitian merupakan penelitian eksperimen yaitu pengaruh ekstrak daun rambutan (Nephelium lappaceum L.) terhadap kematian larva nyamuk Aedes aegypti. Objek penelitian adalah populasi larva nyamuk aedes aegypti. Subjek penelitian yang diambil adalah larva nyamuk Aedes aegypti yang hidup karena pemberian eksfrak daun rambutan (Nephelium lappaceum L.) dengan konsentrasi 5\%, 10\%, $15 \%$.

Penelitian ini dilakukan di kampus Politeknik Kesehatan Kemenkes Aceh, yaitu di laboratorium Jurusan Kesehatan Lingkungan, waktu penelitian dilaksanakan pada bulan Agustus 2017. Pengumpulan data yaitu Data yang diperoleh dari hasil uji atau pengamatan terhadap kematian larva Aedes aegypti dengan pemberian ekstrak daun rambutan (Nephelium lappaceum L.). Serta Data diperoleh dari bahan bacaan diperpustakaan maupun yang bersumber dari media internet.

Pengolahan data dalam penelitian ini dengan Editing yaitu Merupakan kegiatan pengecekan ulang hasil pengamatan apakah sudah sesuai atau belum (relevan atau tidak). Coding yaitu Merupakan kegiatan merubah data berbentuk huruf menjadi data berbentuk angka/bilangan. Kegunaan coding adalah untuk mempermudah pada saat analisis data dan juga mempercepat pada saat entry data. Tabulating yaitu Data yang sudah benar kemudian dimasukkan dalam tabel distribusi frekuensi dan narasi.

Analisis data dilakukan Untuk mengetahui perbedaan ekstrak daun rambutan (Nephelium lappaceum L.) sebagai insektisida alami terhadap kematian larva nyamuk Aedes aegypti, dengan melakukan uji menggunakan rumus anova tunggal dan tabel LSD.

\section{Hasil}

\section{Penggunaan Ekstrak Daun Rambutan (Nephelium lappaceum $\mathbf{L}$.)}

Berdasarkan hasil penelitian yang dilakukan dengan sampel 450 larva nyamuk Aedes aegypty. Maka diperoleh hasil pengaruh ekstrak daun rambutan (Nephelium lappaceum L.) terhadap kematian larva nyamuk Aedes aegypti sebagaimana disajikan pada tabel 1.

Berdasarkan tabel 1 diketahui bahwa dari ketiga perlakuan masing-masing pada kontrol tidak terjadi kematian larva nyamuk Aedes aegyti dikarenakan tidak terkontaminasi dengan ekstrak daun rambutan (Nephelium lappaceum L.). Dari ketiga dosis ekstrak daun rambutan (Nephelium lappaceum L.) dapat disimpulkan bahwa dengan dosis ekstrak daun rambutan $5 \%$ tingkat kematian larva nyamuk Aedes aegypti pada pengulangan pertama berjumlah 18 larva, pada pengulangan kedua 23 larva dan pengulangan ketiga berjumlah 16 larva.

Tabel 1. Jumlah kematian larva nyamuk aedes aegypti pada dosis 5\%, 10\%, 15\% ekstrak daun rambutan (Nephelium lappaceum I.) dengan pengamatan selama 30 menit

\begin{tabular}{|c|c|c|c|c|c|c|c|c|}
\hline \multirow{3}{*}{ Pengulangan } & \multirow{3}{*}{$\begin{array}{c}\text { Larva Aedes } \\
\text { aegypti }\end{array}$} & \multicolumn{7}{|c|}{ Dosis Ekstrak Daun Rambutan (Nephelium lappaceum L.) } \\
\hline & & \multirow{2}{*}{ Kontrol } & \multicolumn{2}{|c|}{ Dosis $5 \%$} & \multicolumn{2}{|c|}{ Dosis $10 \%$} & \multicolumn{2}{|c|}{ Dosis $15 \%$} \\
\hline & & & $f$ & $\%$ & $f$ & $\%$ & $f$ & $\%$ \\
\hline Pertama & 150 & 0 & 18 & 12.0 & 36 & 24.0 & 50 & 33.3 \\
\hline Kedua & 150 & 0 & 23 & 15.0 & 29 & 19.3 & 50 & 33.3 \\
\hline Ketiga & 150 & 0 & 16 & 10.7 & 38 & 25.3 & 31 & 20.7 \\
\hline
\end{tabular}

Sedangkan pada dosis $10 \%$ ekstrak daun rambutan (Nephelium lappaceum L.) tingkat kematian larva nyamuk Aedes agypti pada pengulangan pertama berjumlah 36 larva, pada pengulangan ke dua berjumlah 29 larva dan pada pengulangan ketiga berjumlah 38 larva. Tingkat kematian larva nyamuk Aedes aegypti paling tinggi yaitu pada dosis $15 \%$ masing-masing pada pengulangan pertama dan kedua yaitu 50 larva nyamuk Aedes aegypti. 
Tabel 2. Jumlah rata-rata kematian larva nyamuk Aedes aegypti pada dosis 5\%, 10\%, 15\% ekstrak daun rambutan (Nephelium lappaceum I.) dengan pengamatan selama 30 menit

\begin{tabular}{lcccc}
\hline \multirow{2}{*}{ Pengulangan } & \multirow{2}{*}{ Kontrol } & \multicolumn{3}{c}{ Dosis Ekstrak Daun Rambutan (Nephelium lappaceum L.) } \\
\cline { 3 - 5 } & & Dosis 5\% & Dosis 10\% & Dosis 15\% \\
\hline Pertama & 0 & 18 & 36 & 50 \\
Kedua & 0 & 23 & 29 & 50 \\
Ketiga & 0 & 16 & 38 & 31 \\
Jumlah & 0 & 59 & 103 & 131 \\
Rata-rata & 0 & 19.7 & 34.3 & 43.7 \\
\hline
\end{tabular}

Berdasarkan tabel 2 Diketahui bahwa jumlah rata-rata kematian larva nyamuk aedes aegypti dengan tiga kali pengulangan pada dosis $5 \%$ yaitu jumlah rata-rata 19,7 , pada dosis $10 \%$ jumlah ratarata kematian larva nyamuk Aedes aegypti 34,3 dan pada dosis $15 \%$ jumlah rata-rata kematian larva nyamuk Aedes aegypti yaitu 43,7. Oleh karena itu, berdasarkan hasil penelitian yang sudah didapat, maka dapat dihitung uji statistik dengan menggunakan uji anova sebagaimana disajikan pada tabel 3.

Tabel 3. Hasil uji anova terhadap jumlah kematian larva nyamuk aedes aegypti dengan menggunakan ekstrak daun rambutan (nephelium lappaceum L.)

\begin{tabular}{lccccc}
\hline Sumber Variasi (SV) & $\begin{array}{c}\text { Jumlah Kuadrat } \\
(\mathrm{JK})\end{array}$ & $\begin{array}{c}\text { Derajat } \\
\text { Bebas }(\mathrm{db})\end{array}$ & MK & F-hitung & F-tabel $(\alpha=0,05)$ \\
\hline Kelompok (k) & 3282.8 & 3 & 1094.2 & 28.1 & 4.07 \\
Dalam (d) & 311.4 & 8 & 38.9 & & \\
Total & 3594.2 & 11 & & & \\
\hline
\end{tabular}

Tabel 4. Hasil LSD ekstrak daun rambutan (nephelium lappaceum I) terhadap kematian larva nyamuk aedes egypti

\begin{tabular}{|c|c|c|c|c|c|c|}
\hline \multirow{2}{*}{ Perlakuan terhadap subjek } & & & \multicolumn{4}{|c|}{ Ekstrak daun rambutan (Nephelium lappaceum L) } \\
\hline & & & Kontrol & Dosis $5 \%$ & Dosis $10 \%$ & Dosis $15 \%$ \\
\hline \multirow{4}{*}{$\begin{array}{l}\text { Ekstrak daun rambutan } \\
\text { (nephelium lappaceum } \mathrm{L} \text { ) }\end{array}$} & Kontrol & 0 & 0 & 18 & 23 & 16 \\
\hline & $5 \%$ & 18 & 18 & 0 & $4 *$ & $22 *$ \\
\hline & $10 \%$ & 23 & 23 & 4* & 0 & $19 *$ \\
\hline & $15 \%$ & 16 & 16 & $22 *$ & $19 *$ & 0 \\
\hline
\end{tabular}

*= Selisih mean > LSD, sehingga terdapat perbedaan yang bermakna

Bedasarkan tabel 3 diatas diketahui bahwa derajat kebebasan (Db) 3 (tiga) lawan 8 (delapan) di gunakan untuk melihat F-hitung yaitu kolom ke 3 (tiga) baris ke 8 (delapan), ternyata F-tabel $=4.07$ Nilai F-hitung $=28.1(\mathrm{~F}-$ hitung > F-tabel). Dengan demikian F-hitung lebih besar dari F-tabel jadi Ho ditolak, Ha diterima berarti terdapat perbedaan yang bermakna antara berbagai konsentrasi ketiga perlakuan dengan menggunakan ekstrak daun rambutan (Nephelium lappaceum L.).

Hasil perhitungan, LSD (least significance difference) didapat nilai 4 maka selisih mean > LSD, jadi ada perbedaan yang sangat bermakna antara berbagai dosis dari perlakuan ekstrak daun rambutan (Nephelium lappaceum L.).

\section{Pembahasan}

Kematian larva nyamuk aedes aegypti dengan penggunaan ekstrak daun rambutan (nephelium lappaceum I.)

Berdasarkan hasil penelitian diperoleh bahwa ketiga dosis ekstrak daun rambutan (Nephelium lappaceum L.) dapat disimpulkan bahwa dengan dosis ekstrak daun rambutan $5 \%$ tingkat kematian larva nyamuk Aedes aegypti pada pengulangan pertama berjumlah 18 larva, pada pengulangan kedua 23 larva dan pengulangan ketiga berjumlah 16 larva.

Sedangkan pada dosis $10 \%$ ekstrak daun rambutan (Nephelium lappaceum L.) tingkat kematian larva nyamuk Aedes agypti pada pengulangan pertama berjumlah 36 larva, pada pengulangan ke dua berjumlah 29 larva dan pada 
pengulangan ketiga berjumlah 38 larva. Tingkat kematian larva nyamuk Aedes aegypti paling tinggi yaitu pada dosis $15 \%$ masing-masing pada pengulangan pertama dan kedua yaitu 50 larva nyamuk Aedes aegypti.

Berdasarkan hasil pengamatan yang dilakukan terhadap larva Aedes aegypti setelah diberi ekstrak daun rambutan (Nephelium lappaceum L.), larva menunjukan perubahan warna tubuhnya menjadi gelap dan gerakannya melambat. Larva kelihatan mati tetapi.

Apabila disentuh terdapat gerakan tubuh yang lemah kemudian mati dan ukuran larva mati lebih panjang dibanding sebelum perlakuan yaitu sebelum perlakuan panjang larva sekitar $5 \mathrm{~mm}$ dan setelah kematian menjadi $6 \mathrm{~mm}$. bahwa saponin yang masuk dalam larva dapat menurunkan tegangan permukaan selaput mukosa traktus digestivus larva sehingga dinding traktus digestivus menjadi korosif. Selain itu saponin mengakibatkan ukuran larva yang mati lebih panjang sekitar 1-2 $\mathrm{mm}$ dibandingkan sebelum perlakuan, diperkirakan terjadi relaksasi urat daging pada larva yang mendapat makanan yang mengandung hormone steroid, dan warna tubuh larva agak gelap dan gerakannya melambat kemudian mati (Amir \& Widiastuti, 2018).

Jumlah rata-rata kematian larva nyamuk aedes aegypti dengan penggunaan ekstrak daun rambutan (nephelium lappaceum I.)

Jumlah rata-rata kematian larva nyamuk Aedes aegypti dengan tiga kali pengulangan pada dosis $5 \%$ yaitu jumlah rata-rata 19.7 , pada dosis $10 \%$ jumlah rata-rata kematian larva nyamuk Aedes aegypti 34.3 dan pada dosis $15 \%$ jumlah rata-rata kematian larva nyamuk Aedes aegypti yaitu 43.7. Selanjutnya terdapat perbedaan yang bermakna antara berbagai konsentrasi ketiga perlakuan dengan menggunakan ekstrak daun rambutan (Nephelium lappaceum L.). Hal ini berarti terdapat perbedaan yang signifikan antara konsentrasi ekstrak etanol daun rambutan (Nephelium lappaceum L.) dengan rata-rata kematian larva Aedes aegyti.

Hal ini berarti bahwa terjadi peningkatan rerata kematian larva Aedes aegypti seiring peningkatan konsentrasi ekstrak etanol daun rambutan (Nephelium lappaceum L.) yaitu semakin tinggi konsentrasi maka semakin tinggi pula rerata kematian larva Aedes aegypti. Hal ini sesuai dengan pendapat Adam yang menyatakan bahwa semakin tinggi konsentrasi larvasida yang diberikan maka semakin tinggi pula rerata kematian larva Aedes aegypti (Trisawa, 2014). Dengan demikian dapat diasumsikan bahwa kematian pada larva uji disebabkan karena kandungan senyawa kimia dalam ekstrak etanol daun rambutan (Nephelium lappaceum L.). Kandungan senyawa kimia daun rambutan (Nephelium lappaceum L.) terdiri dari tanin dan saponin (Lestari et al., 2014).

Senyawa tanin dibagi menjadi dua yaitu tanin yang terkondensasi dan tanin yang terhidrolisis. Tanin terdapat pada berbagai tumbuhan berkayu dan herbal. Sifat senyawa saponin yaitu mempunyai rasa pahit, larut dalam air, merupakan racun kuat untuk ikan. Saponin merupakan golongan senyawa kimia yang dapat digunakan sebagai insektisida. Saponin dan tanin terdapat pada tanaman yang kemudian dikonsumsi serangga, mempunyai mekanisme kerja dapat menurunkan 52 aktivitas enzim pencernaan dan penyerapan makanan, sehingga saponin dan tanin bersifat sebagai racun perut (Sumilih \& Astuti, 2010).

\section{Kesimpulan}

Hasil penelitian dapat disimpulkan bahwa, angka kematian larva nyamuk Aedes aegypti dengan menggunakan eksrak daun rambutan (Nephelium lappaceum L) paling tinggi yaitu pada dosis $15 \%$ selama 30 menit pengamatan. Berbagai konsentrasi pada ketiga perlakuan ekstrak daun rambutan yaitu $5 \%, 10 \%$ dan $15 \%$ sangat efektif terhadap kematian larva nyamuk aedes aegypti.

Saran, hasil penelitian ini hendaknya dapat dimanfaatkan dan dipraktekkan dalam kehidupan sehari-hari, agar dapat mengurangi penggunaan insektisida kimia. Perlu penelitian lanjutan tentang pemanfaatan ekstrak daun rambutan sebagai insektisida nabati dengan dosis yang berbeda dan jenis serangga lainnya. Serta dapat menggunakan ekstrak daun rambutan untuk insektisida nabati terhadap kematian larva nyamuk Aedes aegypti.

\section{Deklarasi Konflik Kepentingan}

Penulis telah menyatakan bahwa pada artikel ini tidak ada maupun terdapat potensi konflik kepentingan baik dari penulis maupun instansi sehubungan dengan penelitian yang telah dilakukan, baik berdasarkan kepengarangan, maupun publikasi. 


\section{Ucapan Terima Kasih}

Ucapan terimakasih disampaikan kepada Direktur Politeknik Kesehatan Kemenkes Aceh yang telah membantu anggaran dana penelitian dan berkontribusi terhadap pelaksanaan penelitian. Selain itu, ucapan terima kasih juga kami sampaikan kepada Bapak pembimbing/ supervisor yang telah membantu perbaikan baik secara teknis maupun isi dalam pelaksanaan penelitian ini.

\section{Daftar Rujukan}

Amir, R., \& Widiastuti, Y. (2018). Implementasi ekstrak daun rambutan (Nephelium lappaceum I.) Sebagai pestisida nabati terhadap larva nyamuk aedes aegypti. Jurnal Ilmiah Manusia Dan Kesehatan, 1(1), 53-59.

Desinta, T. (2014). Penentuan Jenis Tanin Secara Kualitatif dan Penetapan Kadar Tanin dari Kulit Buah Rambutan (Nephelium Lappaceum L.) Secara Permanganometri. CALYPTRA, 4(1), 1-10.

Kemenkes RI. (2013). Informasi pengendalian penyakit dan penyehatan lingkungan. In Ditjen PP-PL.

Lestari, D., Nuryati, A., \& Nuryani, S. (2014). Penggunaan Berbagai Konsentrasi Ekstrak Ethanol Daun Rambutan (Nephelium Lappaceum L.) terhadap Mortalitas Larva
Culex Quinquefasciatus. Jurnal Teknologi Laboratorium, 3(1), 46-51.

Listiyati, A. K., Nurkalis, U., \& Hestiningsih, R. (2012). Ekstraksi Nikotin Dari Daun Tembakau (Nicotina Tabacum) Dan Pemanfaatannya Sebagai Insektisida Nabati Pembunuh Aedes Sp. Jurnal IImiah Mahasiswa, 2(2), 67-70.

Moehammadi, N. (2005). Potensi Biolarvasida Ekstrak Herba Ageratum conyzoides Linn. dan Daun Saccopetalum horsfieldii Benn terhadap Larva Nyamuk Aedes aegypti L. Jurnal Berk. Panel. Hayati, 10(1), 1-4.

Siregar, F. A. (2014). Epidemiologi dan pemberantasan demam berdarah dengue (DBD) di Indonesia. In Fakultas Kesehatan Masyarakat, Universitas Sumatera Utara. Universitas Sumatera Utara.

Sumilih, S., \& Astuti, D. (2010). Efektivitas Ekstrak Lempuyang Wangi (Zingiber aromaticum Val.) dalam Membunuh Larva Aedes aegypti.

Trisawa, I. M. (2014). Perkembangan penelitian, formulasi, dan pemanfaatan pestisida nabati. Jurnal Penelitian Dan Pengembangan Pertanian, 32(4), 150-155.

Widiyanti, N. L. P. M., \& Muyadihardja, S. (2004). Uji Toksisitas Jamur Metarhizium Anisopliae Terhadaplarva Nyamuk Aedes Aegypti. Media Penelitian Dan Pengembangan Kesehatan, 14(3), 25-30. 